\title{
CLINICAL APPLICATION OF A MULTIMODAL ELECTROPHYSIOLOGICAL TEST BATTERY TO PREDICT OPTIMAL BEHAVIORAL LEVELS IN COCHLEAR IMPLANTEES
}

\author{
Raghunandhan Sampathkumar ${ }^{1}$, Ravikumar A. ${ }^{2}$, Mohan Kameswaran $^{1}$, Kalyani Mandke $^{3}$, \\ Ranjith R. ${ }^{1}$
}

${ }^{1}$ Department of Implant Otology, Madras ENT Research Foundation, Chennai, India

${ }^{2}$ Department of Otolaryngology, H \& N Surgery, Sri Ramachandra University, Chennai, India

${ }^{3}$ Department of Audiology, Mandke Hearing Services, Pune, India

Corresponding author: Raghunandhan Sampathkumar, Department of Implant Otology, Madras ENT Research Foundation, Chennai, India, e-mail: raghunandhansampath@gmail.com

\begin{abstract}
Objectives: Indications for cochlear implantation have expanded to include very young children and those with syndromes or multiple handicaps. In such cases programming the implant based on behavioral responses may be tedious, wherein matching effective and appropriate measurable auditory percepts (maps) and becomes the key issue in the rehabilitation program. In 'difficult to map' scenarios, objective measures become paramount for predicting optimal current levels to be set in the map. We aimed (a) to study the trends in multi-modal electrophysiological tests and behavioral responses sequentially over the first year of implant use, (b) to generate normative data from the above, (c) to correlate the multi-modal electrophysiological thresholds levels with behavioral comfort levels, and (d) to create predictive formulas for deriving optimal comfort levels (if unknown), using linear and multiple regression analysis.
\end{abstract}

\begin{abstract}
Materials and methods: This prospective study included 10 profoundly hearing impaired children aged 2 to 7 years with normal inner ear anatomy and no additional handicaps. They received the Advanced Bionics HiRes 90K implant with Harmony speech processor and used the HiRes-P with Fidelity 120 strategy. They underwent impedance telemetry, neural response imaging, electrically evoked stapedial response telemetry, and electrically evoked auditory brainstem response tests at 1,4 , 8 , and 12 months of implant use, in conjunction with behavioral mapping. Trends in electrophysiological and behavioral responses were analysed using paired $t$-tests. Using Pearson's correlation method, electrode-wise correlations were derived for NRI thresholds versus M-levels, and offset-based (apical, mid-array, and basal array) correlations for EABR and ESRT thresholds versus M-Levels were calculated over time. These were used to derive predictive formulae by linear and multiple regression analysis. Such statistically predicted M-levels were compared with the behaviorally recorded M-levels among the cohort, using Cronbach's alpha reliability test method for confirming the efficacy of this method.
\end{abstract}

Results: NRI, ESRT, and EABR thresholds showed statistically significant positive correlations with behavioral M-levels, which improved with implant use over time. These correlations were used to derive predicted M-levels using regression analysis. Such predicted M-levels were found to be close to the actual behavioral M-levels recorded among this cohort and proved to be statistically reliable.

Conclusions: The study has explored the trends and correlations between electrophysiological tests and behavioral responses, recorded over time among a cohort of cochlear implantees. It provides a statistical method which may be used as a guideline to predict optimal behavioral levels in difficult situations among future implantees. In 'difficult to map' scenarios, the best outcomes will come from following a protocol of sequential behavioral programming in conjunction with electrophysiological correlates.

Keywords: cochlear implant (CI) • impedance telemetry (IT) • evoked compound action potential (ECAP) • neural response imaging (NRI) • electrically evoked stapedial response telemetry (ESRT) • electrically evoked auditory brainstem response $(\mathrm{EABR}) \cdot$ measurable auditory percept $(\mathrm{map}) \bullet$ most comfortable level $(\mathrm{M}-\mathrm{level}) \bullet$ clinical unit $(\mathrm{CU})$ 


\title{
APLICACIÓN CLÍNICA DEL CONJUNTO MULTIMODAL DE PRUEBAS ELECTROFISIOLÓGICAS PARA PREVISIÓN DE NIVELES ÓPTIMOS DE LAS RESPUESTAS DE COMPORTAMIENTO DE LOS USUARIOS DE IMPLANTES COCLEARES
}

\begin{abstract}
Resumen
Objetivos: El grupo de personas con indicaciones para insertar los implantes cocleares ha crecido, entre otros, aumentando por los niños muy pequeños y niños con defectos congénitos/defectos congénitos múltiples. En estos casos, la programación del implante en base a los resultados de estudios de comportamiento puede resultar difícil para un audiólogo. En la rehabilitación de dichos pacientes es esencial un ajuste eficaz y configuración adecuada del procesador del habla (mapa/programa). Cuando el ajuste del programa del procesador es difícil, la mejor manera de ajustar los parámetros de estimulación es a través de las pruebas objetivas. Nuestro objetivo es (a) estudiar en los periodos sucesivos la tendencia de los resultados de las pruebas electrofisiológicas multimodales y de respuestas de comportamiento en el primer año de utilización del implante (b) obtener datos normativos en base a lo arriba mencionado, (c) correlacionar los resultados de pruebas electrofisiológicas multimodales con los resultados de las pruebas de comportamiento y (d) crear fórmulas de predicción para la obtención de los niveles óptimos, de mayor comididad, de estimulación (si se desconocen) por medio del análisis de la regresión líneal y múltiple.
\end{abstract}

Materiales y métodos: El estudio prospectivo incluyó a 10 niños con pérdida auditiva de grado profundo de edades de 2 a 7 años con la anatomía normal del oído interno y sin más defectos. Los pacientes recibieron implantes Advanced Bionics HiRes $90 \mathrm{~K}$ con el procesador del habla Harmony, que utilizan la estrategia Fidelity 120 HiRes -P. En el primero, cuarto, octavo y duodécimo mes después de la inserción del implante, los pacientes fueron sometidos a las siguientes pruebas: telemetría de impedancia (IT) estudio visual de respuestas neuronales (NRI), telemetria de reflejos del músculo del estribo eléctricamente inducidos (ESRT), estudio de respuestas auditivas del tronco encefálico eléctricamente inducidas (EARB), en combinación con el mapeo del comportamiento. Las tendencias de respuestas electrofisiológicas y de comportamiento se analizaron mediante la realización de la prueba t-Student para muestras dependientes (paired t-test). Para electrodos individuales en períodos subsiguientes se calculó el coeficiente de correlación de Pearson entre el umbral de respuestas neurales y el nivel óptimo de estimulación y el coeficiente compensado de correlación (para los tramos pico, centrales y basales de los electrodos) entre los umbrales de respuestas auditivas eléctricamente evocadas del tronco cerebral y los reflejos del músculo del estribo y el nivel óptimo de estimulación.

En base a los coeficientes de correlación mediante el análisis de regresión líneal y múltiple, se han calculado las fórmulas de predicción. Los niveles óptimos de comodidad de estimulación, calculados estadísticamente, han sido comparados con los niveles óptimos de comodidad de estimulación, registrados a través de comportamiento en el grupo de pacientes- objeto del estudio; se calculó el coeficiente alfa de Cronbach para confirmar la fiabilidad de este método.

Resultados: Los umbrales de NRI, ESRT y EABR han mostrado correlaciones positivas estadísticamente significativas con los niveles óptimos de comportamiento de estimulación que estaban mejorando en el tiempo durante el uso del implante. Aplicando el análisis de regresión sobre la base de la correlación, se ha calculado los niveles óptimos esperados de la estimulación óptima. Se ha constatado que eran similares a los óptimos y cómodos niveles de estimulación observados en el grupo de pacientes y se han resultado ser estadísticamente fidedignos.

Conclusiones: En el presente estudio se han analizado las tendencias y correlaciones entre los resultados de las pruebas electrofisiológicas y respuestas de comportamiento, observados con el tiempo en un grupo de usuarios de implantes cocleares; el estudio presenta un método estadístico que puede aplicarse como una guía para predecir los resultados óptimos de estimulación de comportamiento en los casos, en los que la configuración adecuada del procesador en el paciente resulte difícil. En tales casos, cuando el ajuste correcto del programa del procesador del habla sea difícil, los mejores resultados serán garantizados mediante la aplicación del protocolo de programación secuencial de comportamiento en combinación con los resultados correspondientes de las pruebas electrofisiológicas.

Palabras clave: implante coclear • impedancia telemétrica • potenciales de acción compuestos ECAP • estudio visual de respuestas neuronales NRI • telemetria de reflejos del músculo del estribo eléctricamente inducidos ESRT • estudio de respuestas auditivas del tronco encefálico eléctricamente inducidas EARB • programación del procesador del habla • el nivel óptimo de la estimulación M-Level 


\section{КЛИНИЧЕСКОЕ ПРИМЕНЕНИЕ МУЛЬТИМОДАЛЬНОГО НАБОРА ЭЛЕКТРОФИЗИОЛОГИЧЕСКИХ ТЕСТОВ ДЛЯ ТОГО, ЧТОБЫ ПРЕДВИДЕТЬ ОПТИМАЛЬНЫЕ УРОВНИ БИХЕВИОРАЛЬНЫХ ОТВЕТОВ У ПОЛЬЗОВАТЕЛЕЙ УЛИТКОВЫХ ИПЛАНТАТОВ}

\section{Изложение}

Цели: Группа указаний для вживления улитковых имплантатов расширилась, между прочими, до очень маленьких детей и детей с врожденными пороками/синдромами пороков развития. В таких случаях программирование имплантата на основании результатов бихевиоральных исследований может быть для аудиолога затруднительным. Ключевым в программе реабилитации этих пациентов является приспособление эффективной и соответствующей установки процессора речи (карты/программы). Когда приспособление программы процессора сложно, самым лучшим способом подбора параметров стимуляции стают объективные исследования. Наша цель - (а) исследование в очередных периодах тенденции результатов мультимодальных электрофизиологических тестов и бихевиоральных ответов в первый год использования имплантата, (b) получение нормативных данных на основании вышеизложенного, (c) корреляция результатов мультимодальных электрофизиологических исследований с результатами бихевиоральных исследований и (d) создание прогнозных формул получения оптимальных комфортных уровней стимуляции (если они не известны), с помощью анализа линейного и разнообразного регресса.

Материал и методы: Проспективное исследование охватывало 10 детей с тугоухостью глубокой степени в возрасте от 2 до 7 лет с нормальной анатомией внутреннего уха и без дополнительных нарушений. Пациенты получили имплантаты Advanced Bionics HiRes 90K с процессором речи Harmony, использующие стратегию Fidelity 120 HiRes-P. В первый, четвертый, восьмой и двенадцатый месяц после вживления имплантата, пациенты были подвергнуты следующим исследованиям: импедансная телеметрия (IT), образное исследование нейрональных ответов (NRI), телеметрии рефлексов стремечковой мышцы, электрически вызванных (ESRT), исследование электрически вызванных слуховых стволомозговых ответов (EARB), вместе с бихевиоральным картированием. Тенденции электрофизиологических и бихевиоральных ответов были проанализированы путем проведения теста t-Стъюдента для зависимых выборок (paired t-test). Для отдельных электродов в следующих периодах определен коэффициент корреляции Пирсона между порогом нейральных ответов и оптимальным уровнем стимуляции, а также компенсированный коэффициент корреляции (для предельных, центральных и базовых отрезков электродов) между порогами электрически вызванных слуховых стволомозговых ответов и рефлексов стремечковой мышцы и оптимальным уровнем стимуляции. На основании коэффициентов корреляции с помощью анализа линейного и разнообразного регресса определены предиктивные формулы. Статистически вычисленные оптимальные комфортные уровни стимуляции были сравнены с бихевиорально записанными оптимальными комфортными уровнями стимуляции в исследованной группе пациентов, и определен коэффициент альфа Кронбаха для подтверждения достоверности этого метода.

Результаты: Пороги NRI, ESRT и EABR проявили статистически существенные положительные корреляции с бихевиоральными оптимальными уровнями стимуляции, которые улучшались со временем при использовании имплантата. Используя анализ регресса, на основании корреляции определены прогнозируемые уровни оптимальной стимуляции. Обнаружено, что они были подобными к замаченным оптимальным комфортным уровням стимуляции в исследованной группе пациентов и оказались статистически достоверными.

Выводы: В настоящей работе проанализированы тенденции и корреляции между результатами электрофизиологических исследований и бихевиоральными ответами, замеченными со временем в группе пользователей улитковых имплантатов, а также представлен статистический метод, который может быть использован в качестве показателя для прогнозирования оптимальных бихевиоральных результатов стимуляции в случаях, когда соответствующее приспособление процессора и имплантированного пациента будет затруднительным. В таких случаях, когда тяжело соответствующим образом приспособить программу процессора речи, самые лучшие результаты обеспечит применение протокола последовательного бихевиорального программирования вместе с соответствующими результатами электрофизиологических исследований.

Ключевые слова: улитковый имплантат • телеметрический импеданс • сложные функциональные потенциалы ЕСАР • образное исследование нейрональных ответов NRI • телеметрия рефлексов стремечковой мышцы • электрически вызванных ESRT • исследование электрически вызванных слуховых стволомозговых ответов ЕARB • программирование процессора речи • наиболее оптимальный уровень стимуляции M-Level • клиническая единица CU 


\section{KLINICZNE ZASTOSOWANIE MULTIMODALNEGO ZESTAWU TESTÓW ELEKTROFIZJOLOGICZNYCH W CELU PRZEWIDYWANIA OPTYMALNYCH POZIOMÓW ODPOWIEDZI BEHAWIORALNYCH U UŻYTKOWNIKÓW IMPLANTÓW ŚLIMAKOWYCH}

\section{Streszczenie}

Cele: Grupa wskazań do wszczepienia implantów ślimakowych poszerzyła się m.in. o bardzo małe dzieci i dzieci z wadami wrodzonymi/wielowadziem. W takich przypadkach programowanie implantu na podstawie wyników badań behawioralnych może być dla audiologa uciążliwe. Kluczowe w programie rehabilitacji tych pacjentów jest dopasowanie skutecznego i właściwego ustawienia procesora mowy (mapy/programu). Gdy dopasowanie programu procesora jest trudne, najlepszym sposobem dobrania parametrów stymulacji stają się badania obiektywne. Naszym celem jest (a) zbadanie w kolejnych okresach tendencji wyników multimodalnych testów elektrofizjologicznych i odpowiedzi behawioralnych w pierwszym roku stosowania implantu, (b) uzyskanie danych normatywnych w oparciu o powyższe, (c) skorelowanie wyników multimodalnych badań elektrofizjologicznych z wynikami badań behawioralnych, oraz (d) tworzenie predykcyjnych formuł uzyskiwania optymalnych komfortowych poziomów stymulacji (jeśli nie są znane), za pomocą analizy regresji liniowej i wielorakiej.

Materiał i metody: Badanie prospektywne obejmowało 10 dzieci z niedosłuchem głębokiego stopnia w wieku od 2 do 7 lat z normalną anatomią ucha wewnętrznego i bez dodatkowych upośledzeń. Pacjenci otrzymali implanty Advanced Bionics HiRes $90 \mathrm{~K}$ z procesorem mowy Harmony wykorzystujące strategię Fidelity 120 HiRes-P. W pierwszym, czwartym, ósmym i dwunastym miesiącu od wszczepienia implantu, pacjenci zostali poddani następującym badaniom: telemetrii impedancyjnej (IT), obrazowemu badaniu odpowiedzi neuronalnych (NRI), telemetrii odruchów mięśnia strzemiączkowego wywołanych elektrycznie (ESRT), badaniu elektrycznie wywołanych odpowiedzi słuchowych pnia mózgu (EARB), w połączeniu z mapowaniem behawioralnym. Tendencje odpowiedzi elektrofizjologicznych i behawioralnych zostały przeanalizowane poprzez wykonanie testu t-Studenta dla prób zależnych (paired t-test). Dla poszczególnych elektrod w kolejnych okresach obliczono współczynnik korelacji Pearsona pomiędzy progiem odpowiedzi neuralnych a optymalnym poziomem stymulacji oraz skompensowany współczynnik korelacji (dla szczytowych, środkowych i podstawnych odcinków elektrod) pomiędzy progami elektrycznie wywołanych odpowiedzi słuchowych pnia mózgu i odruchów mięśnia strzemiączkowego a optymalnym poziomem stymulacji. Na podstawie współczynników korelacji za pomocą analizy regresji liniowej i wielorakiej wyliczono formuły predykcyjne. Statystycznie obliczone optymalne komfortowe poziomy stymulacji zostały porównane z behawioralnie zarejestrowanymi optymalnymi komfortowymi poziomami stymulacji w badanej grupie pacjentów, i obliczono współczynnik alfa Cronbacha dla potwierdzenia rzetelności tej metody.

Wyniki: Progi NRI, ESRT i EABR wykazały statystycznie istotne dodatnie korelacje z behawioralnymi optymalnymi poziomami stymulacji, które polepszały się w czasie podczas używania implantu. Stosując analizę regresji, na podstawie korelacji obliczono przewidywane poziomy optymalnej stymulacji. Stwierdzono, że były one zbliżone do zaobserwowanych optymalnych komfortowych poziomów stymulacji w badanej grupie pacjentów i okazały się statystycznie wiarygodne.

Wnioski: W niniejszej pracy zanalizowano tendencje i korelacje pomiędzy wynikami badań elektrofizjologicznych i odpowiedziami behawioralnymi, zaobserwowanymi w czasie w grupie użytkowników implantów ślimakowych i przedstawia metodę statystyczną, która może być stosowana jako wskazówka do przewidywania optymalnych behawioralnych wyników stymulacji w przypadkach, w których odpowiednie ustawienie procesora u pacjenta implantowanego będzie utrudnione. W takich przypadkach, gdy trudno jest odpowiednio dopasować program procesor mowy, najlepsze wyniki zapewni zastosowanie protokołu sekwencyjnego programowania behawioralnego w powiązaniu z odpowiednimi wynikami badań elektrofizjologicznych.

Słowa kluczowe: implant ślimakowy • impedancja telemetryczna • złożone potencjały czynnościowe ECAP • obrazowe badanie odpowiedzi neuronalnych NRI • telemetria odruchów mięśnia strzemiączkowego wywołanych elektrycznie ESRT • badanie elektrycznie wywołanych odpowiedzi słuchowych pnia mózgu EARB • programowanie procesora mowy • najbardziej optymalny poziom stymulacji M-Level • jednostka kliniczna CU.

\section{Background}

Cochlear implantation has been established as a successful time-tested technology for restoration of hearing in individuals with bilateral severe to profound hearing loss. The inclusion criteria for CI has expanded today to include candidates ranging from post-lingual adults with partial high frequency hearing loss to children with congenital profound hearing loss, as young as 6 months of age. As many young children and those with multiple disabilities or syndromic associations are being implanted today, even experienced audiologists may face the daunting task of programming 'difficult to map' children using conventional methods. Children with multiple handicaps may have cognitive problems, developmental delay, and attention deficits, often making it difficult to elicit consistent responses from them. Behavioral responses may be inconsistent in such cases, since they depend upon age, listening experience, and cognitive abilities [1,2]. In such scenarios, objective electrophysiological tests pave the way forward 
Table 1. Clinical data of study group

\begin{tabular}{|c|c|c|c|c|c|}
\hline \multicolumn{6}{|c|}{ Clinical data of study group } \\
\hline Subject & $\begin{array}{c}\text { Age at present/ } \\
\text { sex }\end{array}$ & $\begin{array}{l}\text { Lingual } \\
\text { status }\end{array}$ & $\begin{array}{l}\text { Significant } \\
\text { aetiology }\end{array}$ & $\begin{array}{l}\text { H. aid usage prior to } \\
\text { implantation }\end{array}$ & $\begin{array}{c}\text { Age at } \\
\text { implantation }\end{array}$ \\
\hline 1 & $5 / M$ & Pre-lingual & Birth asphyxia & 2 years & 4 years 3 months \\
\hline 2 & $4 / M$ & Pre-lingual & None & 1 year & 3 years 1 months \\
\hline 3 & $3 / M$ & Pre-lingual & Pre-term Birth & Nil & 2 years 5 months \\
\hline 4 & $3 / M$ & Pre-lingual & Consanguinity & 8 months & 2 years \\
\hline 5 & $8 / F$ & Pre-lingual & Kernicterus & 3 years (irregular use) & 6 years 10 months \\
\hline 6 & $5 / M$ & Pre-lingual & Consanguinity & 3 years & 4 years \\
\hline 7 & $7 / M$ & Pre-lingual & Familial H. loss & 4 years (irregular use) & 5 years 7 months \\
\hline 8 & $4 / F$ & Pre-lingual & Pre-term Birth & Nil & 2 years 9 months \\
\hline 9 & $5 / M$ & Pre-lingual & None & 1 year (irregular use) & 4 years 9 months \\
\hline 10 & $6 / F$ & Pre-lingual & Consanguinity & 2 years & 5 years \\
\hline
\end{tabular}

to program an initial map for them. Studies have shown that post-operative objective electrophysiological tests like ECAP, ESRT, and EABR thresholds correlate well with behavioral levels and these measurements may be used to ascertain an optimal behavioral map for the implantee $[1,2]$.

In clinical practice, when a 'difficult to map' scenario is anticipated or encountered, audiologists may perform an intra-operative or post-operative electrophysiological test like ECAP measurement (NRI/NRT/ART) or ESRT, in order to get an idea of the optimal current level required for stimulation via the implant. They incorporate these current levels into the programming software to set a baseline map at switch-on, and further refine the levels, thenceforth using psychophysical behavioral responses of the child. This method is quite successful for providing a working map for the child at switch-on, and later fine-tuning of the map is based on the child's habilitation performance and psychoacoustic feedback. Sometimes in clinical practice there have been situations where a child's behavioral mapping levels were found to be inappropriate or erroneous and hence the habilitation outcomes were sub-optimal [2]. Such children may return to the audiologist for trouble-shooting and re-mapping.

Recent mapping software has provision for incorporating the electrophysiological current levels (tested intra-operatively or post-operatively) into the programming module for setting an ideal map. Sometimes such a method has not been very successful, due to an inherent disparity between the electrophysiological current levels and the actual behavioral current levels which need to be set in the map. While ECAP thresholds help to identify the current levels required to stimulate the auditory nerve, they may not evoke an optimal behavioral response from the child when set in the map. This disparity has been traced to variation in parameters like stimulation rate and pulse duration while measuring an ECAP and while programming a map [3]. A higher stimulation rate is used in mapping for optimal processing of stimuli, while a lower stimulation rate is preferred while performing ECAP measurements, since accurate electrophysiological thresholds can thus be identified [3]. The literature reports that ECAP thresholds may be successfully recorded in $80-83 \%$ of cases, but are not sensitive enough to identify accurate mapping levels. ESRT is known to overpredict the optimal behavioral comfort levels during the initial period of habilitation, and EABR, though reliable, is found to be cumbersome, time-consuming, and impractical to be done for all electrodes in order to comprehensively program a cochlear implantee [2,4-6]. Hence, no single electrophysiological test has been found to have high sensitivity and reliability for setting an ideal map [7].

In the literature, especially in the Indian context, there is a lack of normative data and reference values for correlation of electrophysiological thresholds and behavioral responses, which may be used as guideline for programming cochlear implantees. This practical fact triggered the need for this study, which began with the hypothesis that correlations of various electrophysiological tests with behavioral levels, recorded in a cohort, would help to statistically predict reliable and optimal behavioral levels (when unknown) using linear and multiple regression models, rather than using a single electrophysiological threshold for direct incorporation into the map, which has been the conventionally followed clinical method.

\section{Materials and Methods}

\section{Study design}

This prospective multi-centre clinical study was performed at the Cochlear Implant Electrophysiology Lab and Habilitation Clinic, Madras ENT Research Foundation (MERF), Chennai, and at the Cochlear Implant Program Centre of Sri Ramachandra University (CLIPS), Chennai, over 2 years from May 2010 to May 2012. The study included 10 non-syndromic, pre-lingual, profoundly hearing impaired children aged 2 to 7 years with normal inner ear anatomy and no additional handicaps (Table 1 ). They received 
the Advanced Bionics HiRes 90K implant with Harmony speech processor and used the HiRes-P with Fidelity 120 strategy. After counselling regarding the test protocol, a written and informed consent was obtained from the parents of these children prior to their inclusion. This research work was approved by the institutional ethics committees of both centers.

\section{Objectives}

The study aimed to develop a statistical method which could be used to program 'difficult to map' cochlear implantees. The objectives were (a) to study the trends in multi-modal electrophysiological tests and behavioral responses, sequentially from the time of switch-on over a period of 1 year of rehabilitation; (b) to generate normative data for electrophysiological tests and behavioral responses based on the trends; (c) to correlate the multi-modal electrophysiological thresholds levels with behavioral comfort levels; and (d) to create predictive formulas for deriving optimal behavioral comfort levels, based on their electrophysiological correlations, using linear and multiple regression statistical methods.

\section{Methods}

All children underwent multi-modal electrophysiological tests - impedance telemetry, neural response imaging, electrically evoked stapedial response telemetry, and electrically evoked auditory brainstem responses - at intervals after switch-on of $1,4,8$, and 12 months, in conjunction with sequential behavioral mapping, as per standard rehabilitation protocols. At each schedule conventional psychophysical behavioral mapping was performed prior to conducting electrophysiological tests, in order to record the actual comfort levels, while the children were fully alert and cooperative. Electrophysiological tests were performed on the same day or on the subsequent day, when the child was cooperative or sedated and sleeping. The testing sequence was staged as follows: impedance telemetry, EABR (for 3 offsets across the array: EL 1 in apical array, EL 8 in midarray, and EL 16 in basal array), NRI (electrode-wise), and ESRT (for 3 offsets across the array: EL 1 in apical array, EL 8 in mid-array, and EL 16 in basal array). EABR was tested first when the child was asleep or sedated since it required a tedious set up, was time-consuming, and EEG disturbances and muscle artifacts needed to be minimal during the test. NRI was performed following EABR, and ESRT was tested last, since most children were averse to the loudness of the stimuli and would otherwise not cooperate for further testing. In between tests, adequate rest time was allowed in order to obtain maximum cooperation from the child and to avoid fatigue. Most children (7 of 10) needed to be sedated for EABR testing, while a few children ( 3 of 10) needed sedation for ESRT testing, since they were not cooperative. No child required sedation more than once at each schedule, and with experience these tests could be performed faster, while the children were asleep after an afternoon meal. In cases where satisfactory recordings were not obtained, due to technical issues or patient noncompliance, tests were repeated the next day. Thus, the authors could successfully acquire all required data within 2 days for each child.

\section{Techniques}

All electrophysiological and mapping current levels were recorded in clinical units (CUs), which represents the basic unit of stimulus intensity used in the testing and programming software (Soundwave version 2.0.33). The Advanced Bionics HiRes $90 \mathrm{~K}$ cochlear implant system was connected to the Soundwave software via a Platinum speech processor (PSP) during the various tests. Default stimulus parameters for pulse duration and stimulation rate were maintained during electrophysiological measurements, since any change would introduce a bias in the values measured between various electrodes across the array and at subsequent test schedules. 3 If a representative electrode showed no response during testing, the test was repeated on the subsequent day and in three cases extrapolated data from the adjacent electrodes were used for statistical analysis in the study. The threshold for all objective measures was defined as the lowest stimulation level at which a response was identified as present. Visual inspection of characteristic peaks was performed by an experienced audiologist for each objective measure in order to identify and confirm the thresholds of stimulation. The learning curve was difficult in the initial period of the study, due to various issues like technical and software snags, stimulus artifacts, and electrical interference (especially with EABR), patient compliance (especially with ESRT), and other logistic reasons.

\section{Mapping protocol}

The Advanced Bionics cochlear implant uses a fitting technique based on comfort level. Programming is based on 'most comfortable' levels (M-levels), while the threshold level (T-Level) for each electrode is auto-set by the software at $10 \%$ of the M-level values in clinical units. This helps to maintain an optimal dynamic range throughout the period of rehabilitation. Using this conventional mapping technique at each schedule of programming, psychophysical behavioral comfort levels (M-levels) were sequentially obtained across the array, and these were incorporated into the speech processor as the most stable and preferred map for the child. M-levels were determined by increasing stimulus intensity until the child indicated that the sound was loud but tolerable. Younger children, whose ability to judge the loudness was limited, were monitored for eye blinking, crying, and changes in facial expression or activity level during and shortly after stimulus presentation, in order to identify their M-levels. An in-house child psychologist and the mothers of these young children were also part of the tests, in order to help identify the appropriate behavioral responses.

\section{EABR testing}

For recording EABR, the non-inverting electrode was placed at the center mid-line of the head (CZ), inverting electrodes were placed on each mastoid, and a ground electrode was placed on the forehead of the child. Recordings from the channel using the ipsilateral mastoid electrode were used for statistical analysis. Electrodes passed through an analogue low pass filter $(\sim 32 \mathrm{kHz})$ to essentially eliminate artifacts from the transmitting coil signal before entering the pre-amplifier. The signal was filtered at 
10 to $3000 \mathrm{~Hz}$, and the amplifier was set at 150,000. EABR stimulus was delivered by SCLIN2000 software (version $1.08)$ with electrical pulses of $25 \mu$ of alternating polarity presented at a repetition rate of $11-31 \mathrm{~Hz}$. This pulse was carried by the trigger cable via the PSP processor onto the implant and the response was received by a pre-amplifier and sent to the Intelligent Hearing Systems SmartEP (evoked potential) software (version 3.91USBez) in a paired computer to synchronise the recording window with the stimulus presentation. Recordings on the IHS SmartEP module were made between 5 and $80 \mathrm{~ms}$ relative to stimulus onset, and a time window of $10 \mathrm{~ms}$ was used for visual inspection of the EABR waveforms. Three representative electrodes from the three offsets created across the array (apical array EL 1, mid-array EL 8, and basal array EL 16) were used for EABR testing. Larger intensity steps of $10 \mathrm{CU}$ were used for EABR to minimize test time, in an effort to complete testing for all three electrodes across the array at one sitting while the children were asleep or sedated. In a few cases, EABR waveforms were interspersed with non-auditory waveforms or artifacts, and in these cases a polarity reversal with adjustments of high/low pass filter settings needed to be done in order to overcome ambiguity and clearly identify EABR responses. If the EEG activity was grossly interfering with identification of EABR responses, the child was rescheduled for another test under sedation on the subsequent day. While recording EABR, it was observed that waves, e(III) and e(V) were clearly recordable between 2 to $7 \mathrm{~ms}$, with their amplitudes being more prominent at higher intensity levels. The EABR threshold level was identified as the lowest intensity of stimulus which evoked a consistent, clearly recognisable wave $\mathrm{e}(\mathrm{V})$ and this was considered as confirmation of a brainstem response to electrical stimulation via the implant.

\section{ECAP testing}

NRI thresholds were serially obtained using the in-built ECAP module of the Soundwave 2.0.33 software, with automated settings for all electrodes across the array. The default stimulation range was between 100 to $350 \mathrm{CU}$, with a cathode-first stimulation sequence, gain of 300, and 128 averages per data point. The EP growth function was sequentially monitored at various stimulation levels by the appearance of typical N1-P2 waveforms, and the NRI threshold was identified as the lowest intensity of stimulus which evoked a recognisable ECAP response on the Soundwave software.

\section{ESRT testing}

Stapedius reflex measurement was performed in the implanted ear after confirming normal middle ear function with tympanometry. A tone-burst pulse train stimulus from the Soundwave software at $500 \mathrm{~ms}$ intervals with $18 \mu$ s pulse width and 3712 pps channel rate in automated pulse width mode was used to trigger ESRT responses, which were recorded on the reflexometer of the Interacoustics AZ 26 impedance bridge. We used four representative electrodes from offsets of four electrodes created across the array for measuring ESRT responses: namely EL 1 (EL 1 to 4) in the apical array, EL 6 (EL 5 to 8) and EL 11 (EL 9 to 12) in the mid array, and EL 16 (EL 13 to 16 ) in the basal array. ESRT thresholds were identified to be that minimal stimulus level which evoked a recognisable deflection on the reflexometer. If a response was determined to be present, the stimulus level was decreased in steps of 5 $\mathrm{CU}$ until the response was absent in the recording. ESRT thresholds were accepted as present if three clear immittance deflections were observed on the reflexometer for a particular stimulus level.

\section{Statistical analysis}

Data was analysed by a bio-statistician using the SPSS 17.0 software. Trends in electrophysiological and behavioral responses of the auditory nerve recorded during the study were analysed using the paired $t$-test and normatives were obtained for this cohort. Using Pearson's correlation method, electrode-wise correlations were derived for NRI versus M-level, and offset-based correlations for ESRT and EABR versus M-level were calculated sequentially over time. The following reference range was used for correlations: $r<0.001=$ no significant correlation, 0.001 to $0.300=$ poor correlation, 0.301 to $0.700=$ moderate correlation and 0.701 to $0.999=$ good correlation. These correlations were used to derive predictive formulas by linear and multiple regression analysis. By this method NRI, ESRT, and EABR values recorded for a representative electrode across the array could be placed into the regression formula to derive an optimal M-level for that electrode (if unknown). This predicted value could be used as a reference to program that electrode. Such statistically predicted M-levels were compared with the actual (behaviorally recorded) M-levels among the study group using Cronbach's alpha reliability test method. The following reference range was used: $R<0.001=$ no significant reliability, 0.001 to $0.400=$ poor reliability, 0.401 to $0.700=$ moder ate reliability and 0.701 to $0.999=$ good reliability.

\section{Observations and results}

\section{Trends in impedance telemetry}

Impedance changes were monitored through each schedule of electrophysiological testing. The mean average impedance levels ranged between $4.8 \mathrm{k} \Omega$ to $7.9 \mathrm{k} \Omega$ across the array. The initial impedance measurements when checked at the first month of implant use were found to be higher than subsequent measurements, and a trend of higher impedance levels in the apical and basal array was observed in the study group. The overall impedance values in the mid-array electrodes were lesser by a mean average of $1.58 \mathrm{k} \Omega( \pm 0.30 \mathrm{SD})$ than the apical and basal electrodes at 1 year of follow up. This was statistically significant with a $p$ value of 0.034 . The impedance levels across the array stabilised over time with implant use.

\section{Trends in behavioral M-levels}

Electrode-wise trends in psychophysical behavioral comfort levels when observed over time showed a sequential gradual rise in M-levels across the array, starting from a mean average of $155 \mathrm{CU}$ at the first month of implant use to $272 \mathrm{CU}$ by the end of 1 year of implant use. This signified an expansion in the dynamic range of implantaided hearing, as the children's auditory perception skills 
and capacity to tolerate higher intensity sounds through the implant improved over time of implant use. M-levels gradually rose from the apical electrodes towards the basal array. M-levels were higher by an average of $36.3( \pm 7$ SD) CU between the apical and basal arrays at completion of 1 year of implant use. This was statistically significant with a $p$ value of 0.017 . The higher M-levels noted in the basal array imply that louder impulses were required to address the basal region of the cochlea, which has a higher density of spiral ganglia and codes for higher frequencies of auditory stimulation.

\section{Trends in ECAP thresholds}

NRI thresholds were typically lower than M-levels and were stable across the electrode array at all schedules of testing. NRI thresholds ranged between an average of 113 ( $\pm 11 \mathrm{SD}$ across the means) CU, noted at first schedule, to 202 ( \pm 18 SD across the means) CU at 1 year of implant use. A gradual rise was observed in NRI thresholds from the apical array towards the basal array in the study group.

\section{Trends in ESRT thresholds}

An offset-wise analysis of electrodes for trends in ESRT thresholds showed a gradual rise from the apical array towards the basal array. The initial ESRT thresholds, recorded at the first month of implant use, showed a mean average value of $173 \mathrm{CU}$ across the array, while the corresponding mean value for $\mathrm{M}$-levels across the array was $155 \mathrm{CU}$. This supports the fact, documented in the literature $[1,2]$, that in the initial period of implant use ESRT thresholds may over-estimate the comfort levels, so that they may be a good indicator of maximum comfort levels rather than most comfortable levels. Hence, audiologists setting an ESRT-based initial map for an uncooperative child must be cautious in order to avoid any mapping level above the ESRT thresholds, which may induce an uncomfortable response to acoustic stimulation in the child and aversion to further implant use. At later stages of implant use, we observed that ESRT levels gradually rose with time and fell in close proximity to the most comfortable levels, with the mean ESRT value across the array at 1 year being $275 \mathrm{CU}$ compared to the corresponding M-level of $272 \mathrm{CU}$. The overall ESRT thresholds increased over time with a mean rise of 82.5 ( $\pm 16 \mathrm{SD}$ ) CU between the first and fourth schedules of testing. This was statistically significant with a $p$ value of 0.028 .

\section{Trends in EABR thresholds}

EABR thresholds were higher than ECAP thresholds, but lower than ESRT thresholds in the study. The authors infer that EABR thresholds were higher due to the need for a higher energy of stimulation via CI that is required to elicit a recordable action potential from the brainstem. EABR thresholds gradually rose from the apical electrodes towards the basal array. EABR thresholds were higher by an average of 46.8 ( \pm 7 SD) CU and 54.5 ( $\pm 11 \mathrm{SD}) \mathrm{CU}$ in the basal array compared to the apical array, at 1 month and 1 year of implant use respectively. This was statistically significant with a $p$ value of 0.050 . Through all schedules of testing, EABR responses were quite stable among all the three offsets along the electrode array. There was not much of a change in EABR thresholds, except by a few CUs, when recorded in the same electrode over time. This supports the fact noted in the literature $[5,6]$ that EABR threshold patterns remain unchanged over the first year of implant use, and that EABR is useful for objective programming of implants through the period of rehabilitation. The longitudinal trends observed in electrophysiological tests and comfort levels at the four test schedules are displayed in Figure 1 (offset-wise values) and Figure 2 (overall values).

\section{Correlation and regression analysis}

All correlations recorded between the various electrophysiological tests and behavioral comfort levels were found to be positive throughout the study period, ranging from moderate to good and statistically significant at the level of $p=0.01$ to 0.05 (two-tailed). There were significant correlations between the objective measures and behavioral responses, right from the time of switch-on of the device, and they had a tendency to gradually stabilise and improve over time with implant use. The longitudinal correlations of NRI, ESRT, and EABR versus M-levels measured over time are shown in Figure 3 (overall values) and Figure 4 (offset-wise values). NRI and ESRT correlations with Mlevels were statistically significant at the level of $p<0.05$ (two-tailed), while EABR correlations with M-levels were significant at the level of $p=0.01$ (two-tailed). These figures suggest that EABR correlations are more statistically significant than NRI and ESRT. The significance of EABR depends upon the sample variations within the study cohort and may not directly reflect its sensitivity or usefulness in clinical practice. The sensitivity of EABR in comparison to ECAP and ESRT for objective programming in 'difficult to map' conditions needs to be further investigated in a clinical perspective.

The initial correlation for NRI versus M-level was modest at $r=0.416$, but over time it improved to $r=0.704$. ESRT correlation with M-level proved to be good from the first schedule at $r=0.794$ and it improved gradually to $r=0.927$ by the last schedule. EABR correlation with Mlevel remained stable through the period of study, ranging from $r=0.871$ to 0.824 at the first and fourth schedules respectively.

Cross-correlations between the three electrophysiological tests were found to be moderate, ranging from $r=0.487$ at first schedule to $r=0.493$ at the last schedule. This helped to statistically infer whether there was any undue influence of one test on another when combining them into a multiple regression model. These cross-correlations were significantly lower than the individual longitudinal correlations of the three tests with comfort levels measured in our cohort. Hence, the three correlations could be combined together in a multi-modal regression model for predicting offset-based comfort levels across the array. ESRT and EABR thresholds correlated well with M-levels across the array, ranging from $r=0.697$ to 0.984 at all schedules of testing, with $p$ values of 0.01-0.05 (two-tailed). The NRI thresholds showed poor to moderate correlations with $\mathrm{M}$-levels over time in the apical array, ranging from $r=0.287$ to $0.524(p=0.05)$, while in the mid array and basal array they had moderate to good correlations ranging from $r=0.589$ to $0.891(p<0.03)$. Based on the 


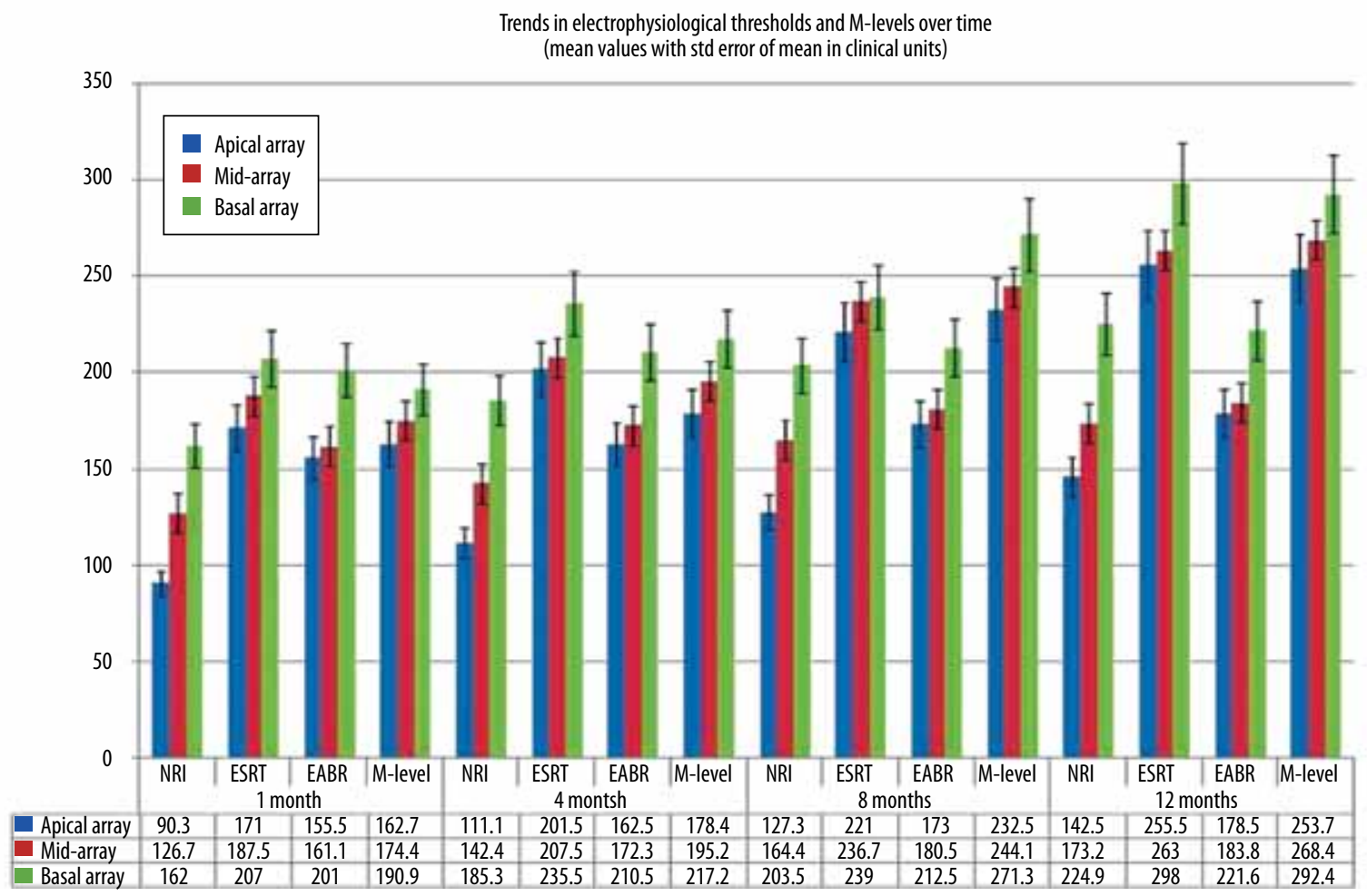

Figure 1. Offset-wise trends in electrophysiological thresholds and M-levels over time (mean values with std error of mean in clinical units, CU)

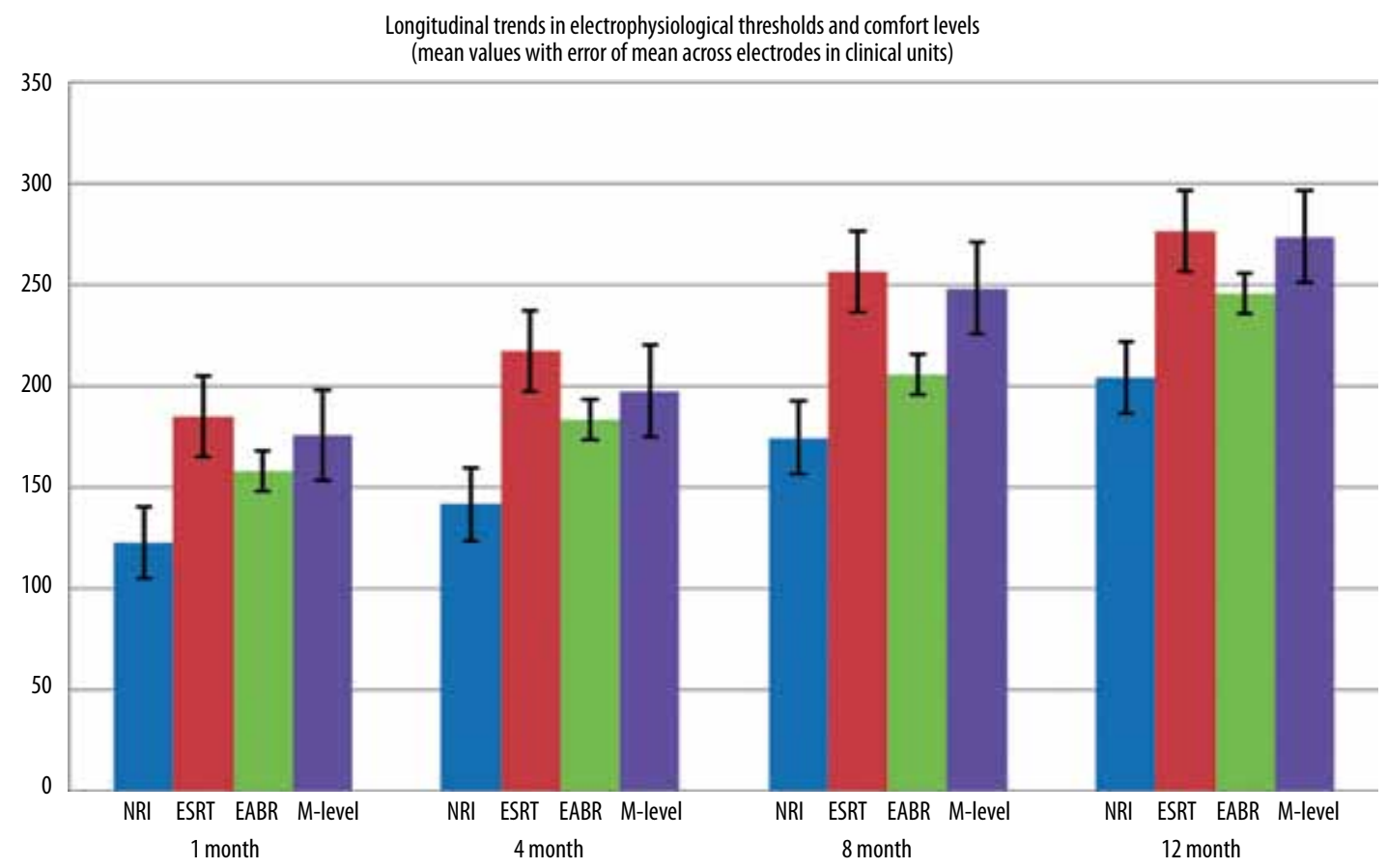

Figure 2. Longitudinal trends in electrophysiological thresholds and comfort levels (mean values with error of mean across electrodes in clinical units, $\mathrm{CU}$ )

electrophysiological correlations, prediction formulas for unknown comfort levels were generated for the first and last schedules using linear and multiple regression analysis.
Electrode-wise prediction formulas were created by linear regression of NRI thresholds (Table 2), while offset-wise (apical, mid-array, and basal) prediction formulas were 


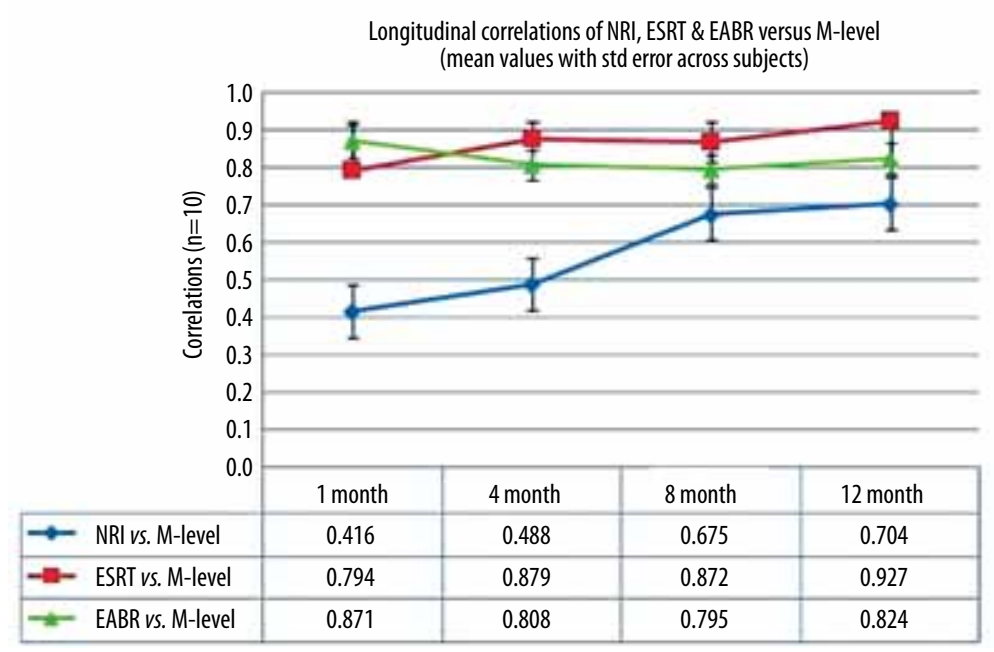

Figure 3. Longitudinal correlations of NRI, ESRT, and EABR vs. M-level (mean values with std error across subjects)

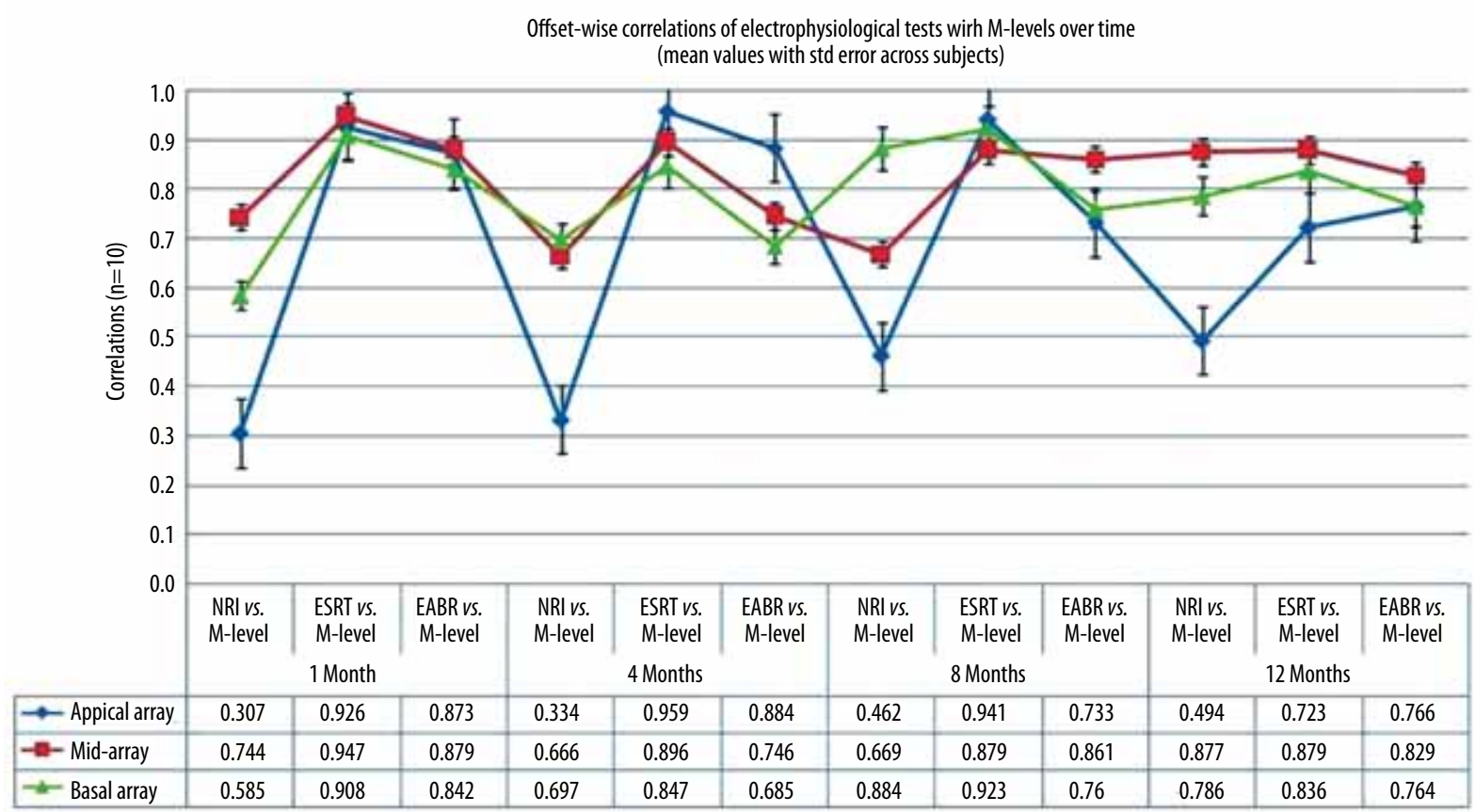

Figure 4. Offset-wise correlations of electrophysiological tests with $\mathrm{M}$-levels over time (mean values with std error across subjects)

obtained by linear regression of ESRT and EABR thresholds (Tables 3 and 4). Offset-wise prediction formulas were also generated by incorporating all three thresholds into a multiple regression model (Table 5).

\section{Reliability analysis}

The predicted M-levels were analysed for their statistical reliability with actual (behavioral) M-levels recorded among the study group (Table 6). Cronbach's alpha reliability test showed that all objective measures had good reliability while predicting $\mathrm{M}$-levels independently. EABR and ESRT showed better reliability values than NRI at the first month, but all three parameters had comparable reliability values at 1 year of implant use. The multi-modal prediction method showed significantly higher reliability values at both 1 month and 1 year of implant use, which suggests that this method may be a better way for predicting comfort levels at any point of time. On clinical application of this statistical method to subjects of our study group, the authors found close proximity of predicted M-levels with actual behavioral M-levels, but there were individual variability, as shown in Tables 7 and 8 and in the scatterplots of Figures 5 and 6 . When the statistically predicted maps were incorporated into the speech processors of subjects in our study group, these children found it to be as useful as the behavioral map used by them previously. Results from the present study help to infer that multi-modal electrophysiological testing by recording a minimum of three 
Sampathkumar et al. - Clinical Application of a Multimodal Electrophysiological Test Battery to Predict...

Table 2. NRI threshold based electrode-wise linear regression formulas

\begin{tabular}{|c|c|c|}
\hline \multicolumn{3}{|c|}{ NRI based linear regression formulae } \\
\hline $\mathrm{N}=10$ & 1 month & 12 month \\
\hline Overall (mean avg) & M-level =128.743 + $0.328 \times \mathrm{NRI}$ & M-level $=167.004+0.522 \times \mathrm{NRI}$ \\
\hline Electrode 1 & M-level =158.448 + $0.047 \times \mathrm{NRI}$ & M-level $=200.790+0.330 \times \mathrm{NRI}$ \\
\hline Electrode 2 & M-level $=151.003+0.126 \times \mathrm{NRI}$ & M-level $=169.300+0.521 \times \mathrm{NRI}$ \\
\hline Electrode 3 & M-level = $127.783+0.399 \times \mathrm{NRI}$ & M-level $=203.736+0.362 \times \mathrm{NRI}$ \\
\hline Electrode 4 & M-level =151.063 + $0.119 \times \mathrm{NRI}$ & M-level $=176.271+0.453 \times \mathrm{NRI}$ \\
\hline Electrode 5 & M-level $=99.999+0.697 \times \mathrm{NRI}$ & M-level $=193.782+0.411 \times \mathrm{NRI}$ \\
\hline Electrode 6 & M-level $=32.612+1.172 \times \mathrm{NRI}$ & M-level $=181.862+0.438 \times \mathrm{NRI}$ \\
\hline Electrode 7 & M-level $=95.631+0.653 \times \mathrm{NRI}$ & M-level $=107.588+0.797 \times \mathrm{NRI}$ \\
\hline Electrode 8 & M-level $=83.028+0.721 \times \mathrm{NRI}$ & M-level $=115.912+0.764 \times \mathrm{NRI}$ \\
\hline Electrode 9 & M-level =112.175 + $0.457 \times \mathrm{NRI}$ & M-level $=140.257+0.612 \times \mathrm{NRI}$ \\
\hline Electrode 10 & M-level =136.794 + $0.304 \times \mathrm{NRI}$ & M-level $=162.118+0.532 \times \mathrm{NRI}$ \\
\hline Electrode 11 & M-level = $149.247+0.235 \times \mathrm{NRI}$ & M-level $=147.838+0.609 \times \mathrm{NRI}$ \\
\hline Electrode 12 & M-level $=174.052+0.068 \times \mathrm{NRI}$ & M-level $=184.322+0.443 \times \mathrm{NRI}$ \\
\hline Electrode 13 & M-level $=135.955+0.378 \times \mathrm{NRI}$ & M-level $=156.155+0.590 \times \mathrm{NRI}$ \\
\hline Electrode 14 & M-level $=134.603+0.374 \times \mathrm{NRI}$ & M-level $=90.912+0.863 \times \mathrm{NRI}$ \\
\hline Electrode 15 & M-level $=134.788+0.365 \times \mathrm{NRI}$ & M-level $=136.086+0.630 \times \mathrm{NRI}$ \\
\hline Electrode 16 & M-level $=123.957+0.440 \times \mathrm{NRI}$ & M-level $=118.190+0.711 \times \mathrm{NRI}$ \\
\hline
\end{tabular}

Table 3. ESRT threshold based offset-wise linear regression formulas

\begin{tabular}{ccc}
\hline & ESRT based linear regression formulae & \\
\hline $\mathbf{N}=\mathbf{1 0}$ & $\mathbf{1}$ month & $\mathbf{1 2}$ month \\
\hline Overall (mean avg) & M-level $=43.504+0.713 \times$ ESRT & M-level $=88.262+0.671 \times$ ESRT \\
\hline Electrode 1 & M-level $=49.439+0.662 \times$ ESRT & M-level $=103.148+0.589 \times$ ESRT \\
\hline Electrode 6 & M-level $=42.252+0.724 \times$ ESRT & M-level $=71.844+0.7111 \times$ ESRT \\
\hline Electrode 11 & M-level $=35.300+0.795 \times$ ESRT & M-level $=94.218+0.653 \times$ ESRT \\
\hline Electrode 16 & M-level $=39.813+0.695 \times$ ESRT & M-level $=104.152+0.632 \times$ ESRT \\
\hline
\end{tabular}

Table 4. EABR threshold based offset-wise linear regression formulas

\begin{tabular}{|c|c|c|}
\hline \multicolumn{3}{|c|}{ EABR based linear regression formulae } \\
\hline $\mathbf{N}=10$ & 1 month & 12 month \\
\hline Overall (mean avg) & M-level $=43.765+0.703 \times A E B R$ & M-level $=76.739+0.704 \times$ AEBR \\
\hline Apical array (El 1) & M-level $=40.994+0.735 \times A E B R$ & M-level $=70.976+0.729 \times A E B R$ \\
\hline Mid array (El 8) & M-level $=19.575+0.819 \times$ AEBR & $M$-level $=68.318+0.734 \times A E B R$ \\
\hline Basal array (El 16) & M-level $=71.064+0.572 \times A E B R$ & M-level $=88.200+0.665 \times A E B R$ \\
\hline
\end{tabular}

offset-based electrophysiological thresholds may be helpful in predicting optimal most comfortable levels (when unknown) across an array. Such data may be a reference point for performing similar studies among complex, difficult to map implantees in future. At present the authors are pursuing an on-going study to look into the application of this method for programming a spectrum of 'difficult to map' situations.

\section{Discussion}

Behavioral responses are sufficient to obtain optimal threshold and comfort levels for programming the majority of the post-lingual adult cochlear implantees. Although these levels are reasonably accurate at the time of programming, the threshold and comfort levels tend to change over time and hence sequential re-programming 
Table 5. Multi-modal (NRI + ESRT + EABR) thresholds based offset-wise multiple regression formulas

\begin{tabular}{|c|c|c|}
\hline \multicolumn{3}{|c|}{ NSI + ESRT + EABR based multiple regression formulae } \\
\hline $\mathbf{N}=10$ & 1 month & 12 month \\
\hline Overall & $\begin{array}{c}\text { M-level }=44.147-0.011 \times \mathrm{NRI}+0.635 \times \mathrm{ESRT} \\
+0.083 \times \mathrm{EABR}\end{array}$ & $\begin{array}{c}\text { M-level }=64.048+0.159 \times \mathrm{NRI}+0.387 \times \mathrm{ESRT} \\
+0.248 \times \mathrm{EABR}\end{array}$ \\
\hline Apical array (El 1) & $\begin{array}{c}\text { M-level }=66.366-0.186 \times \mathrm{NRI}+0.762 \times \mathrm{ESRT} \\
-0.104 \times \mathrm{EABR}\end{array}$ & $\begin{aligned} \text { M-level }=35.891 & +0.146 \times \mathrm{NRI}+0.395 \times \mathrm{ESRT} \\
& +0.373 \times \mathrm{EABR}\end{aligned}$ \\
\hline Mid array (El 8) & $\begin{array}{c}\text { M-level }=51.877-0.098 \times \mathrm{NRI}+0.783 \times \mathrm{ESRT} \\
-0.153 \times \mathrm{EABR}\end{array}$ & $\begin{array}{c}\text { M-level }=75.512+0.396 \times \mathrm{NRI}+0.352 \times \mathrm{ESRT} \\
+0.065 \times \mathrm{EABR}\end{array}$ \\
\hline Basal array (El 16) & $\begin{array}{c}\text { M-level }=36.739-0.073 \times \mathrm{NRI}+0.772 \times \mathrm{ESRT} \\
+0.026 \times \mathrm{EABR}\end{array}$ & $\begin{aligned} \text { M-level }=64.106 & +0.192 \times \mathrm{NRI}+0.351 \times \mathrm{ESRT} \\
& +0.250 \times \mathrm{EABR}\end{aligned}$ \\
\hline
\end{tabular}

Table 6. Cronbach's alpha reliability test results for the study group. Actual (behavioral) vs. predicted M-level

\begin{tabular}{ccc}
\hline \multicolumn{2}{c}{ Cronbach's alpha reliability tests for actual (behavioral) vs. predicted $\mathbf{M}$-level } \\
\hline $\mathbf{N}=\mathbf{1 0}$ & $\mathbf{1}$ month & $\mathbf{1 2}$ month \\
\hline NRI predicted reliability value & 0.546 & 0.823 \\
\hline ESRT predicted reliability value & 0.964 & 0.881 \\
\hline EABR predicted reliability value & 0.932 & 0.895 \\
\hline NRI + ESRT + EABR predicted reliability value & 0.968 & 0.949 \\
\hline
\end{tabular}

of the maps based on behavioral responses is necessary as and when required [5]. On the other hand, establishing accurate behavioral thresholds and comfort levels is extremely challenging for very young children and those with syndromic associations or multiple disabilities. The behavioral observation technique used in infants and toddlers for implant programming is likely to over-estimate threshold measures when compared with procedures used in older children that use conditioned responses [5,6]. Programming very young children is clinically challenging at times for even experienced audiologists. Hence, currently various electrophysiological tests have taken precedence in the programming of such 'difficult to map' individuals.

A suspected disparity between electrophysiological thresholds and behavioral parameters needs to be thought of whenever a cochlear implantee's performance is not up to expectations, as reflected by their poor auditory-verbal skills and general behavior to implant usage. A multitude of electrophysiological tests are clinically available today to help confirm the integrity of the implant in such cases. Intra-operatively and post-operatively EABR, ESRT, and ECAP measurements can be used to assess the device's integrity and to measure the amplitude growth function of the nerve response [4]. Such objective data help in sequentially programming the device and can also be used as possible predictor of implant performance over time [6].

Although all implant manufacturers provide, along with their programming software, commercially available standardised testing modules for performing electrophysiological tests like ESRT, EABR, and ECAP, they do not stress the necessity to routinely perform these tests in order to properly program the implant. By and large, these tests have been used for trouble-shooting and for research purposes. In newer software, there is an option to import ECAP thresholds into the mapping module for optimal setting of current levels. But often, a single objective measurement like ECAP may not correlate and predict behavioral levels accurately [7]. This may be due to inherent differences in the pulse width and rate of stimulation, which exist between the electrical response of the auditory nerve recorded as an ECAP and the actual behavioral response used to program the implant [3].

Gordon et al. stated that, when behavioral results are questionable, electrophysiological thresholds might be useful to provide young children using cochlear implants with audible and comfortable auditory inputs, from which they can learn to detect sounds. Once they detect the auditory stimulation provided, these children begin to learn and respond consistently to discrete stimulus presentations. As this ability improves, reliable behavioral stimulation levels are obtained. These authors emphasised that behavioral measures of threshold remain the gold standard of setting minimum stimulation levels. This principle is being followed in the Nucleus cochlear implant system, which uses a threshold level based programming technique. However, these authors concluded that current clinical techniques may not be the best methods for determining maximum stimulation levels. This aspect of their observation induced interest in performing the present study, since identifying the most comfortable levels seems to be the pivotal factor in programming a 'difficult to map' child using the Med El or Advanced Bionics implant systems (which both use a comfort level based programming technique). Hence, the present study focuses on utilising objective measures to predict optimal comfort levels for a cohort of comparable cochlear implantees.

The literature has documented comparisons between intra-operative and post-operative electrophysiological responses of the auditory nerve $[4,5]$, and these papers conclude that there is a definite variation in the current levels, 
Sampathkumar et al. - Clinical Application of a Multimodal Electrophysiological Test Battery to Predict...

Table 7. Comparison of behavioral vs. predicted M-levels at 1 month in the study group

\begin{tabular}{|c|c|c|c|c|c|c|}
\hline \multicolumn{7}{|c|}{ Comparision of behavioral vs. predicted $M$-levels at 1 month in the study group } \\
\hline Subject & Electrodes & $\begin{array}{c}\text { Behavioral } \\
\text { M-level }\end{array}$ & $\begin{array}{l}\text { NRI predicted } \\
\text { M-level }\end{array}$ & $\begin{array}{l}\text { ESRT predicted } \\
\text { M-level }\end{array}$ & $\begin{array}{l}\text { EABR predicted } \\
\text { M-level }\end{array}$ & $\begin{array}{c}\text { NRI + ESRT + } \\
\text { EABR predicted } \\
\text { M-level }\end{array}$ \\
\hline \multirow{3}{*}{1} & El 1 & 165 & 189.85504 & 171.80172 & 149.27158 & 169.17961 \\
\hline & El 8 & 176 & 172.28522 & 175.36556 & 166.85607 & 174.91785 \\
\hline & El 16 & 189 & 187.94528 & 186.05707 & 191.47435 & 186.89629 \\
\hline \multirow{3}{*}{2} & El 1 & 170 & 179.92427 & 200.31241 & 184.44055 & 199.00563 \\
\hline & El 8 & 184 & 176.88885 & 211.00392 & 202.02504 & 210.68757 \\
\hline & El 16 & 230 & 201.31363 & 221.69543 & 219.60952 & 221.59187 \\
\hline \multirow{3}{*}{3} & El 1 & 98 & 149.63805 & 114.78304 & 117.61951 & 115.77562 \\
\hline & El 8 & 103 & 155.09734 & 104.08883 & 135.20400 & 108.14675 \\
\hline & El 16 & 127 & 167.31983 & 150.41870 & 159.8227 & 151.99306 \\
\hline \multirow{3}{*}{4} & El 1 & 144 & 167.31983 & 132.59952 & 149.27158 & 134.86913 \\
\hline & El 8 & 164 & 169.99350 & 150.41870 & 145.75469 & 150.26598 \\
\hline & El 16 & 177 & 192.52871 & 186.05707 & 170.37296 & 184.28948 \\
\hline \multirow{3}{*}{5} & El 1 & 140 & 166.1737 & 150.41870 & 128.17020 & 148.30965 \\
\hline & El 8 & 151 & 196.34824 & 150.41870 & 166.85607 & 151.99765 \\
\hline & El 16 & 177 & 208.95288 & 182.49323 & 180.92366 & 181.88659 \\
\hline \multirow{3}{*}{6} & El 1 & 116 & 146.69438 & 114.78304 & 135.20400 & 117.91556 \\
\hline & El 8 & 139 & 157.38906 & 129.03569 & 152.78848 & 132.38575 \\
\hline & El 16 & 172 & 165.79202 & 150.41870 & 152.78848 & 151.21053 \\
\hline \multirow{3}{*}{7} & El 1 & 183 & 167.31983 & 171.80172 & 149.27158 & 169.81685 \\
\hline & El 8 & 189 & 179.92427 & 186.05707 & 184.44055 & 186.29737 \\
\hline & El 16 & 204 & 195.96629 & 207.44009 & 184.44055 & 204.90614 \\
\hline \multirow{3}{*}{8} & El 1 & 272 & 151.27781 & 275.15298 & 254.77849 & 274.79142 \\
\hline & El 8 & 280 & 214.30002 & 257.33379 & 254.77849 & 257.12398 \\
\hline & El 16 & 246 & 206.27901 & 243.07845 & 272.36297 & 246.70687 \\
\hline \multirow{3}{*}{9} & El 1 & 184 & 150.89586 & 150.41870 & 149.27158 & 151.21889 \\
\hline & El 8 & 193 & 164.28421 & 168.23789 & 163.33917 & 168.37766 \\
\hline & El 16 & 204 & 169.99350 & 186.05707 & 184.44055 & 186.57819 \\
\hline \multirow{3}{*}{10} & El 1 & 155 & 163.50030 & 171.80172 & 184.44055 & 174.05354 \\
\hline & El 8 & 165 & 184.88968 & 168.23789 & 194.99124 & 171.51024 \\
\hline & El 16 & 183 & 171.90326 & 196.74858 & 194.99124 & 197.29399 \\
\hline
\end{tabular}

which may be attributed to factors like wound healing (with reduction in the neural tissue/electrode interface), alteration of the electro-chemical gradient within the cochlea, neural re-organisation within the cochlea, and adaptation of the auditory nerve to become more conducive for electrical stimulation over time $[5,6,8]$. It is believed that impedance to current passage reduces over time as synchronous firing for electrical stimuli via the implant sets in. With implant usage over time, the higher auditory centers also become more receptive and fine-tuned for stimulation through the cochlear implant. Hence, rather than relying upon intra-operative measures, post-operative electrophysiological tests are more efficient in predicting mapping levels [9]. The present study has explored this 
Table 8. Comparison of behavioral vs. predicted M-levels at 12 months in the study group

\begin{tabular}{|c|c|c|c|c|c|c|}
\hline \multicolumn{7}{|c|}{ Comparision of behavioral vs. predicted M-levels at 12 months in the study group } \\
\hline Subject & Electrodes & $\begin{array}{c}\text { Behavioral } \\
\text { M-level }\end{array}$ & $\begin{array}{l}\text { NRI predicted } \\
\text { M-level }\end{array}$ & $\begin{array}{l}\text { ESRT predicted } \\
\text { M-level }\end{array}$ & $\begin{array}{l}\text { EABR predicted } \\
\text { M-level }\end{array}$ & $\begin{array}{c}\text { NRI + ESRT + } \\
\text { EABR predicted } \\
\text { M-level }\end{array}$ \\
\hline \multirow{3}{*}{1} & El 1 & 200 & 247.43980 & 215.7112 & 210.57104 & 209.32900 \\
\hline & El 8 & 208 & 236.99359 & 215.7112 & 224.65886 & 211.10507 \\
\hline & El 16 & 244 & 271.98840 & 242.54244 & 252.8390 & 247.20274 \\
\hline \multirow{3}{*}{2} & El 1 & 199 & 255.27446 & 225.77286 & 217.61485 & 220.01058 \\
\hline & El 8 & 208 & 254.22984 & 232.48069 & 217.61485 & 223.56401 \\
\hline & El 16 & 230 & 271.46609 & 255.95810 & 235.22438 & 248.58256 \\
\hline \multirow{3}{*}{3} & El 1 & 262 & 278.25613 & 215.7112 & 273.96533 & 241.07296 \\
\hline & El 8 & 290 & 278.25613 & 289.49725 & 281.00914 & 286.14977 \\
\hline & El 16 & 314 & 311.68401 & 272.72767 & 288.05296 & 289.15331 \\
\hline \multirow{3}{*}{4} & El 1 & 266 & 260.49757 & 282.78942 & 288.05296 & 279.33979 \\
\hline & El 8 & 276 & 287.65772 & 272.72767 & 273.96533 & 276.85638 \\
\hline & El 16 & 300 & 314.81787 & 309.62704 & 309.18439 & 318.85342 \\
\hline \multirow{3}{*}{5} & El 1 & 332 & 316.38480 & 302.91291 & 281.00914 & 305.53097 \\
\hline & El 8 & 334 & 322.65253 & 326.39031 & 323.27201 & 335.88935 \\
\hline & El 16 & 358 & 335.71030 & 349.86772 & 333.83772 & 357.15054 \\
\hline \multirow{3}{*}{6} & El 1 & 224 & 210.35574 & 252.60418 & 224.65886 & 224.27266 \\
\hline & El 8 & 240 & 247.43980 & 276.08159 & 270.44343 & 265.27711 \\
\hline & El 16 & 278 & 290.26927 & 276.08159 & 323.27201 & 296.96428 \\
\hline \multirow{3}{*}{7} & El 1 & 280 & 217.66809 & 296.20508 & 242.26819 & 257.87922 \\
\hline & El 8 & 294 & 275.12266 & 282.78942 & 263.39962 & 275.11582 \\
\hline & El 16 & 312 & 300.71548 & 329.74423 & 295.09677 & 321.20196 \\
\hline \multirow{3}{*}{8} & El 1 & 248 & 258.40832 & 289.49725 & 273.69533 & 277.61020 \\
\hline & El 8 & 268 & 275.1226 & 276.08159 & 302.14058 & 284.89516 \\
\hline & El 16 & 280 & 285.56848 & 276.08159 & 305.66248 & 289.32435 \\
\hline \multirow{3}{*}{9} & El 1 & 250 & 224.98044 & 255.95810 & 238.74628 & 235.63639 \\
\hline & El 8 & 276 & 258.93063 & 242.54244 & 252.83390 & 243.21757 \\
\hline & El 16 & 294 & 294.97007 & 286.14333 & 298.61867 & 295.51994 \\
\hline \multirow{3}{*}{10} & El 1 & 276 & 239.08283 & 259.31201 & 281.00914 & 256.76914 \\
\hline & El 8 & 292 & 275.64457 & 299.55899 & 273.96533 & 288.67900 \\
\hline & El 16 & 314 & 271.98840 & 282.78942 & 288.05296 & 282.84675 \\
\hline
\end{tabular}

relationship from the time of switch-on to the end of the 1 year rehabilitation period.

Assessment of cochlear implantees' functional outcomes depends on a multitude of factors like the age at implantation, etiology and duration of hearing loss, pre-amplification history, cognition, intellect, patient motivation for implant use, and the effectiveness of auditory verbal rehabilitation [9]. Today, it is accepted that ECAP thresholds significantly correlate with both threshold and comfort levels (more so with threshold levels), but raw ECAP data is not adequate for estimating absolute mapping levels in implantees and correction factors are suggested for ECAPs to be of any predictive value. A number of investigators have 


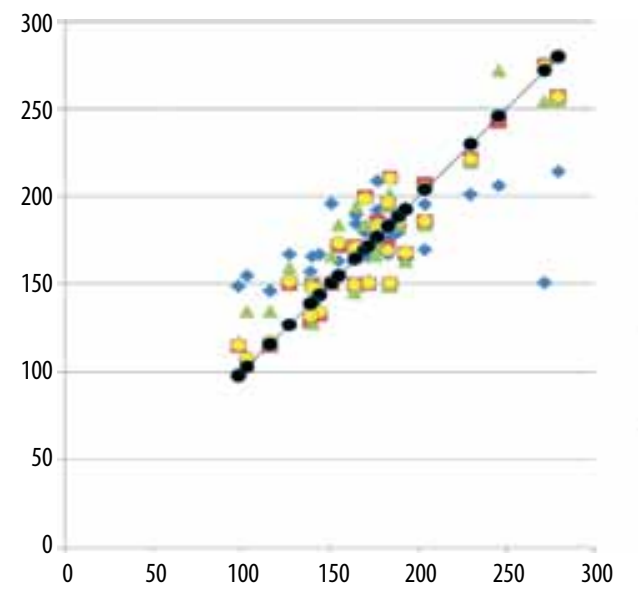

Figure 5. Scatter plot of behavioral vs. predicted M-levels across subjects at 1 month

- NRI predicted M-level

= ESRT predicted M-level

- EABR predicted M-level

$\mathrm{NRI}+\mathrm{ESRT}+\mathrm{EABR}$

predicted M-level

- Behavioral M-level

— Linear (behavioral M-level)

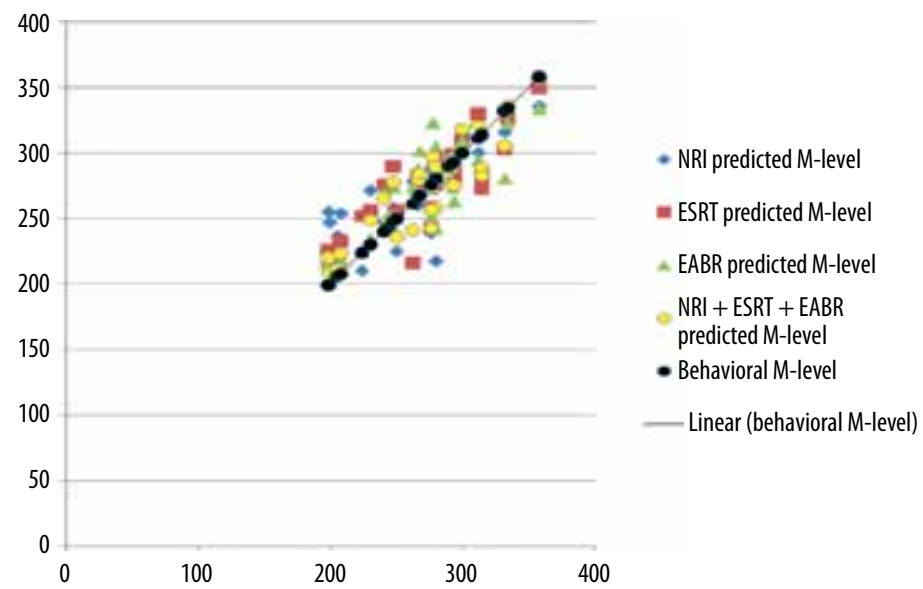

Figure 6. Scatter plot of behavioral vs. predicted $\mathrm{M}$-levels across subjects at 12 months

described various correction factors, and yet there does not seem to be a universal approach for calculating the predicted map values from ECAPs alone [5,7,9-11,15]. The general consensus today is that ECAP, when used alone, is not a very precise and sensitive tool for objectively predicting mapping parameters $[7,9]$.

A study by Thai-Van et al. suggests that the correlation between the neural response thresholds and behavioral thresholds may improve from the base towards the apex of the cochlea. However, a significant correlation can be demonstrated for all tested electrodes at 12 months postimplantation. During the first months, care must be exercised when interpreting neural response telemetry measurements, as a positive test does not necessarily mean that the stimulus delivered to the acoustic nerve will be centrally processed and result in an auditory percept.

Abbas and Hughes in 2001 revealed chronological changes in NRT over time from the day of surgery. Statistically significant changes in the NRT thresholds of children were observed until 3 to 8 months following initial stimulation. Measures of NRT slope in children did not stabilise until 12 months post-implantation, and longitudinal trends in NRT measures mirrored the threshold levels more closely than comfort levels. In the present study, NRT measurements showed moderate correlations with comfort levels over time. There were wide differences between the NRT based predicted levels and behavioral comfort levels across the array, with a range of 6 to 40 CUs noted between subjects. There were inter-electrode and inter-patient variations between the NRT predicted levels and behavioral comfort levels over time. The above observations suggest that NRT based correlation, when used alone, is not a useful method for predicting behavioral comfort levels.

Investigators have assessed the efficacy of ESRT in predicting comfort levels for optimal programming and they have found ESRT to be of greater predictive value than ECAP for estimating behavioral comfort levels $[7,12,13]$. Postoperative ESRT thresholds show high correlations with behaviorally obtained comfort levels and help to predict the maximum comfort level pattern across electrodes [7]. Fitting of the speech processor based on ESRT data has been shown to result in speech perception scores equal to or better than those achieved with conventional fitting techniques [8].

Spivak and Chute found that comfort levels and ESRT thresholds rose over the first year of implant use and the increased tolerance to higher levels of stimulation, as shown by increasing M-levels and ESRT over time, was possibly 
due to changes in condition of the auditory nerve and lower brain stem. Thus, an expanded dynamic range emerges over time and this may suggest a change, with on-going implant use, in neural response with increasing stimulus level. Hence, when programming young children, accurate estimation of comfort levels and loudness balancing are of greater value than setting behavioral threshold levels. In the present study, ESRT correlations with M-levels were found to be better than NRT correlations across the array and over time. Predicted M-levels based on ESRT recorded among the study group, fell closer to the actual behavioral comfort levels than the NRT based predicted M-levels, with a difference of 4 to 21 CUs noted in most cases. Thus, the ESRT based prediction method may be more useful than the ECAP based prediction method, when used alone.

Authors have also found that, similar to ECAPs, EABR thresholds correlate well with behavioral thresholds and they provide a sensitive and effective technique to comprehensively test implant function by assessing neural survival along the cochlea and integrity of the auditory pathway up to brainstem level [5-7]. EABR has been the gold-standard tool for meticulous analysis of individual electrodes along the array, to identify non-auditory electrodes, and confirm device failures. In a poor CI user, EABR helps to identify and redefine erroneous maps which may exist undiagnosed even by ECAP measurements [5,7]. The possible reasons for EABRs not being widely used in clinical practice today is that it requires a cumbersome set up, is time-consuming, and needs expertise and a fully cooperative patient. In the present study, EABR correlations with M-levels were found to be comparable to ESRT correlations. EABR based predicted values for M-levels were close to the actual behavioral comfort levels, with a difference ranging between 3 to 28 CUs across the array. The differences were more pronounced in the apical array and less in the basal array. This suggests that the EABR based prediction method, when used alone, may be useful for predicting comfort levels more towards the base rather than the apex, but the authors believe a further in-depth study is necessary to confirm this finding.

In the past, correction factors proposed to predict threshold and comfort levels from objective measures were based on the difference between objective thresholds and at least one behavioral measure $[5,14,15]$. Subsequent literature has suggested that correction factors based on ECAP, ESRT, and EABR thresholds are needed to predict behavioral levels required for programming in difficult situations [1113]. Various methods have been described for applying objective measures to predict behavioral levels in 'difficult to map' cochlear implantees. One suggested method is to extrapolate the correction factor, calculated based on the difference between the behavioral level and the objective measurement recorded for one representative electrode, across the rest of the array in order to set behavioral levels. But, this technique is not foolproof since there are variations in behavioral levels between the apical and basal array electrodes. Changes in objective and behavioral responses (with respect to the electrode location and over time with ongoing implant use) imply that such correction factors do not remain static. Correction factors may need to be adjusted with increased cochlear implant experience to account for increased awareness and experience with auditory inputs $[14,15]$.

It is now known that all electrodes along an array may not respond to stimulation in the same way [7]. Apical electrodes may have significantly lower thresholds when measured by ESRT, ECAP, EABR, and behavioral measures than basal electrodes [7]. Gordon et al., studied this interesting phenomenon by dividing the electrode array into three offsets - apical array, mid-array, and basal array - and creating a correction factor based on the difference between the objective threshold and behavioral level for a representative electrode in each offset across the array. Gordon observed that electrophysiological thresholds remained quite stable over time, while behavioral responses varied with implant use. She found a tendency toward increased differences over time in the apical electrode and mid-array, with less significant increases in the basal electrode differences over time. She also proposed that ECAP and ESRT can be used independently to predict minimum and maximum stimulation levels, respectively, and thus optimise the dynamic range along the electrode array.

In order to overcome any inherent difference in current levels, observed while using a single measurement like ECAP or ESRT for predicting mapping levels, the present study suggested the use of three objective measures (ESRT, EABR, and ECAP) which together may correlate and predict behavioral levels better. The authors have followed a model of three offsets across the array, similar to Gordon's method, for predicting M-levels based on the linear and multiple regression models, since this can provide at least three optimal predicted M-levels across the array which will be of vital use to begin programming if behavioral levels are unknown. Both linear and multiple regression models are good methods for statistically predicting comfort levels. In cases where good correlations occur for all the three measures, a multiple regression would be more beneficial. A judicious selection of measures is necessary when a situation is encountered in which none of the three measures show a good correlation.

Multiple regression analysis depends upon the sample size of the number of independent variables included in it. The present study had a limited sample size both in terms of the number of patients (10) and the number of electrophysiological parameters performed on a representative electrode (3), which provided 30 data points for analysis for each offset of the electrode array when tested at different times. Hence, the following observations assume that this limited data was statistically adequate to successfully create predicted comfort levels using a multiple regression model.

The multi-modal test method performed in the present study, which used three objective electrophysiological parameters, improved the correlations with the behavioral comfort levels and also the accuracy of prediction, to an extent that was slightly higher than the individual prediction methods. In some subjects, the accuracy was as close as $3 \mathrm{CU}$, which was not observed when using the various linear regression methods, while in other subjects the difference in values ranged between 3 to $29 \mathrm{CU}$ across the array, which was comparable to the individual prediction methods. The authors infer that the multi-modal regression 
method may be more useful than the linear regression method for predicting comfort levels, since it shows higher statistical reliability and predictability potential, but its practical application in the clinical scenario, especially in 'difficult to map' subjects may not be easy, since it requires more testing time and a cooperative subject.

In the present study, when applying the various prediction methods and at the various schedules of testing, individual variabilities and mismatch of a few programming units occurred between the behaviorally measured and statistically predicted comfort levels. This mismatch was pronounced in a few subjects while very minimal in others (Tables 7 and 8; Figures 5 and 6). This was possibly due to the various factors described below. Electrophysiological measurements were performed at default stimulation parameters that were different from the stimulation rates eventually used during cochlear implant programming. Sensitivity and neural reactions recorded to electrophysiological stimuli are bound to be different to the behavioral reactions at the higher rates of stimulation used while programming.

The behavioral response elicited by electrical stimulation with a cochlear implant electrode is understood to be the result of a combination and superposition of the following phenomena occurring at three different levels. Level 1: electrode/tissue impedance and positioning of the electrode contact towards the neural tissue; the higher thresholds for electrophysiological responses at the basal electrodes are possibly due to the physical current distribution. Level 2: neural preservation and excitability of the nerve fibers. Level 3: cortical and behavioral reactions to the excitation patterns in the higher auditory pathways as influenced by the age at onset of deafness, cognition, intellect, hearing aid usage, and duration of hearing deprivation prior to implantation. All electrophysiological measurements like ECAP, EABR, and ESRT objectively record events occurring at levels 1 and 2, yet take no account of the variability present at the higher auditory centers. Behavioral responses are immensely influenced by higher auditory circuits and electrophysiological measurements of the peripheral auditory system alone cannot substitute or replace a behavioral map accurately.

Behavioral responses to stimulation via an implant vary widely between very young children and older children, where factors at level 3 play a major role, and there is also inter-personal variability between subjects. This fact is notable from the results of the present study, which has included implantees whose age ranges from 2 to 7 years. Hence, age may be the factor explaining the differences noted between the behavioral and predicted M-levels across subjects of the study group, The advent of cortical auditory evoked potentials (CAEP) has provided some interesting insights into the events occurring at level 3 with respect to age among cochlear implantees. Studying correlations between cochlear implant aided acoustic/electrically evoked CAEPs and behavioral levels may probably provide a way forward to overcome the mismatches that occur when applying current methods.

The results of the study infer that behavioral measurements, even if minimally recordable, are essential for programming cochlear implantees, and that electrophysiological measurements may help in guiding programming but cannot replace or substitute for behavioral levels. Results have shown that electrophysiological testing, by recording a minimum of three offset-based electrophysiological thresholds, is helpful in predicting comfort levels across the array and provides a working map when behavioral levels are unknown or minimally available. Performing such multi-modal predictions gives additional information on the range of comfort levels, and helps in refining/confirming behavioral levels when they are doubtful. Thus, a combination of both measures provides the most optimal levels for programming in 'difficult to map' situations. Data based on the correlations and prediction methods described in the study may serve as a reference for similar studies among complex, 'difficult to map' implantees in future. At present, the authors are pursuing an ongoing study looking at the application of this method for programming a spectrum of 'difficult to map' situations.

\section{Conclusions}

The study has explored the trends and correlations between electrophysiological thresholds and behavioral comfort levels, recorded over time, among a cohort of comparable cochlear implantees. Although inter-patient and inter-electrode variables were bound to affect this study, an overall trend was observed in the electrical and behavioral responses of the auditory nerve over time. These trends provide a way, using regression analysis, to correlate the various parameters and to derive predictive formulas for calculating optimal behavioral comfort levels. When clinically applied, this method was found to be useful for programming members of the study group, but due to various factors there remained individual disparities of a few programming units between the actual and predicted comfort levels among the study group. Hence, it is essential to obtain behavioral inputs for programming all implantees, although this study method may be used as reference for additional inputs in order to generate an optimal map. Objective measures of implant function are vital, especially while programming very young cochlear implantees and those with special needs. In such cases, following a protocol of behavioral programming, in conjunction with multimodal electrophysiological correlations as described in the study, may provide the best outcomes.

\section{References:}

1. Spivak LG, Chute PM. The relationship between electrical acoustic reflex thresholds and behavioral comfort levels in children and adult cochlear implant patients. Ear Hear, 1994; 15(2): 184-92
2. Hodges AV, Butts SL, King JE. Electrically evoked stapedial reflexes -: utility in cochlear implant patients. In: Cochlear Implants: Objective Measures. 1st Edn; Whurr Publishers, (London, Philadelphia), 2003; S: 81-93. 
3. Davids T, Valero J, Papsin BC, Harrison RV, Gordon KA. Effects of stimulus manipulation on electrophysiological responses of pediatric cochlear implant users. Part I: Duration effects and Part II: Rate effects. Hearing Research, 2008; 244: 7-24.

4. Mason S. Electrophysiologic and objective monitoring of the cochlear implant during surgery: implementation, audit and outcomes. Int J Audiol, 2004; 43: S33-38.

5. Abbas PJ, Hughes, ML, Brown CJ, Luk B, Wolaver A, Gervais J. The relationship between EAP \& EABR thresholds and levels used to program the Nucleus 24 speech processor: Data from adults. Ear and Hearing, 2000; 21: 151-63.

6. Brown, Carolyn J. Clinical uses of electrically evoked auditory nerve and brainstem responses. Curr Opin Otolaryngol Head Neck Surg, 2003; 11(5): 383-87.

7. Gordon KA, Papsin BC, Harrison RV. Toward a battery of behavioral and objective measures to achieve optimal cochlear implant stimulation levels in children. Ear Hear, 2004; 25: $447-63$.

8. Shallop JK, Ash KR. Relationships among comfort levels determined by cochlear implant patient's self-programming, audiologist's programming, and electrical stapedius reflex thresholds. Ann Otol Rhinol Laryngol Suppl, 1995; 166: 175-76

9. Thai-Van H, Chanal JM, Coudert C, Veuillet E, Truy E, Collet L. Relationship between NRT measurements and behavioral levels in children with the Nucleus 24 cochlear implant may change over time: preliminary report. Int J Pediatr Otorhinolaryngol, 2001; 58: 153-62.
10. Smoorenburg GF, Willeboer C, Van Dijk JE. Speech perception in Nucleus CI24M cochlear implant users with processor settings based on electrically evoked compound action potential thresholds. Audiol Neurootol, 2002; 7: 335-47.

11. Di Nardo W, Ippolito SW, Quaranta N, Cadoni G, Galli J. Correlation between NRT measurement and behavioural levels in patients with the Nucleus 24 cochlear implant. Acta Otolaryngol Italica, 2003; 23: 352-55.

12. Han DM, Chen XQ, Zhao XT, Kong Y, Li YX, Liu S et al. Comparisons between Neural Response Imaging thresholds; electrically evoked auditory reflex thresholds and most comfortable loudness levels in CII Bionic Ear users with HiRes sound processing strategies. Acta Otolaryngo, 2005; 125(7): 732-35.

13. Caner G, Olgun L, Gültekin G, Balaban M. Optimizing Fitting in Children Using Objective Measures Such as Neural Response Imaging and Electrically Evoked Stapedius Reflex Threshold. Otol Neurotol, 2007; 28(5): 637-40.

14. Hughes ML, Vander Werff KR, Brown CJ, Abbas PJ, Kelsay DM, Teagle HF et al. A longitudinal study of electrode impedance, the electrically evoked compound action potential and behavioral measures in Nucleus 24 cochlear implant users. Ear Hear, 2001; 22(6): 471-86.

15. Zimmerling MJ, Hochmair ES. EAP recordings in CI patients - correlations with psychophysical measures and possible implications for patient fitting. Ear Hear, 2002; 23: 81-91. 